\title{
BAYANG SEBAGAI EKSPLORASI KONFLIK BATIN DALAM VISUALISASI PUISI PADA KARYA SENI VIDEO "KINAN"
}

\author{
Antonius Janu Haryono \\ Sazkia Noor Anggraini \\ Program Studi Film \& Televisi, Fakultas Seni Media Rekam, \\ Institut Seni Indonesia Yogyakarta \\ Jl. Parangtritis km. 6.5 Yogyakarta Telp. (0274) 381047
}

\begin{abstract}
ABSTRAK
Tari merupakan gerak ritmis untuk mengekspresikan ungkapan perasaan dan pikiran melalui tubuh penari. Kinanti Sekar Rahina adalah seorang penari yang mengalami pertentangan batin dalam menentukan eksistensi dirinya sebagai penari tradisional dan pertemuannya dengan tarian modern. Karya "Kinan" yang diambil dari namanya merupakan bentuk visualisasi dari karya puisi yang dibuatnya. Karya ini menggunakan media seni video untuk memvisualisasikan konflik batin seorang penari, lewat eksplorasi bayang. Bayang menjadi simbol dari keinginan Kinan menjadi seorang penari balet sedangkan dirinya sendiri menjadi objek dari realitas sebagai perempuan Jawa yang harus melestarikan tarian Jawa. Visualisasi konflik tersebut pada awalnya diperlihatkan dengan adu tarian antara sang penari dengan bayangnya, namun kemudian konflik diselesaikan dengan sebuah tari kreasi paduan tradisional dan modern yang divisualisasikan dengan sinkronisasi antara penari dan bayangnya. Pengambilan gambar dilakukan dua kali untuk membuat visual efek bayangan yang seolah-olah hidup. Proses memadukan bayang dan objek dilakukan dengan teknik cropping dengan dua buah gambar yang ukuran dan latarnya sama. Pengubahan sudut sumber cahaya digunakan untuk mendapatkan gambar bayangan yang lebih jauh sehingga memudahkan cropping.
\end{abstract}

Kata Kunci: Bayangan, Konflik Batin, Visualisasi Puisi

\section{ABSTRACT}

Dance is a rhythmic motion to express feelings and thoughts through the dancer's body. Kinanti Sekar Rahina is a dancer who experiences inner conflicts while questioning her existence as a traditional dancer and her encounters with modern dance. The video artwork "Kinan" which is taken from her name, is a visualization of her poetry. This artwork uses video art media to visualize a dancer's inner conflicts through shadow exploration. The shadow is a symbol of Kinan's desire to become a ballet dancer. Meanwhile, she as the object faces the reality as a Javanese woman who obliged conserve Javanese dances. The conflict visualization initially shows by a dance battle between the dancer and her shadow, but then the conflict resolved with a dance created by a combination of traditional and modern visualization, shows by the dancer and the shadow synchronization. To create a visual effect of "alive" shadows, two shots were taken. The process of integrating the shadow and object was done by cropping it with two images of the same size and background. This artwork used to change the angle of the light source to get a further shadow image that makes cropping technique easier.

Keywords : Shadow, Inner Conflict, Poetry Visualization, 


\section{Pendahuluan}

Tarian merupakan media bagi seorang penari untuk mengekspresikan perasaan maupun pikirannya dengan menggunakan gerakan tubuhnya. Setiap gerakan memiliki makna atau pesan yang ingin disampaikan oleh penari kepada penonton. Menurut Kamaladevi Chattopadhaya, seorang ahli tari dari India mengemukakan bahwa tari merupakan desakan perasaan manusia di dalam dirinya yang mendorongnya untuk mencari ungkapan-ungkapan yang berupa gerakgerak yang ritmis (Soedarsono, 1992:81).

Dalam sebuah tari pasti terdapat sebuah gerak. Gerakan tersebut bersifat ritmis, berirama berbeda-beda, sehingga menghasilkan beraneka ragam gerak. Gerak dan ritme merupakan sebuah kesatuan dalam tarian. Gerakan merupakan elemen utama dan ritme adalah elemen kedua. Kedua elemen tersebut juga dapat kita jumpai pada gerakan-gerakan keseharian kita, seperti: berlari, berkelahi, berjalan, dan lainnya. Meski memiliki elemen yang sama, gerakan tari dan yang bukan gerakan tari tetap bisa dibedakan satu sama lain. Menurut Soedarsono, dalam bukunya yang berjudul Pengantar Apresiasi Seni, yang dikategorikan sebagai gerak tari adalah gerak yang telah dirombak. Apa yang dimaksud dengan “dirombak" adalah gerakan yang telah mengalami distorsi atau stilisasi sehingga bentuknya dapat menyentuh perasaan manusia yang melihatnya (Soedarsono, 1992:82).

Desakan perasaan seorang penari dapat berupa konflik batin yang sedang dialami. Seorang penari yang mengalami konflik batin akan merasakan adanya pertentangan dalam dirinya, antara apa yang diinginkan dengan apa yang terjadi, antara harapan dengan kenyataan yang sesungguhnya dialami dan dihadapi. Sebagai seorang penari yang hidup di tengah keluarga dengan kebudayaan Jawa yang kuat dan hidup di era modern saat ini tentu banyak permasalahan-permasalahan yang muncul. Perkembangan teknologi informasi di satu sisi memberikan kemudahan mengakses kebudayaan dan tarian dari bangsa lain. Banyak tari-tarian dari bangsa lain yang sudah berkembang di Indonesia, di antaranya balet, dansa, dan lain-lain. Hal ini dapat memunculkan pertentangan yang harus dihadapi oleh seorang penari, contohnya ketika memiliki cita-cita sebagai seorang penari balet namun di lain pihak dituntut untuk melestarikan tarian tradisionalnya. Pertentangan-pertentangan tersebut dapat diekspresikan melalui gerakan-gerakan yang telah dirombak sehingga penonton dapat ikut merasakan dan atau setidaknya mengetahui perasaan yang sedang dialami oleh penari. 
Konflik batin merupakan konflik dengan diri sendiri. Mengungkapkan konflik batin yang dialami seorang penari agar dengan mudah dapat ditangkap oleh penontonnya dapat menggunakan beberapa cara. Konflik jenis ini akan sulit dipahami oleh penonton jika hanya ditarikan secara sendirian tanpa menggunakan bantuan media lain. Biasanya sebuah tarian yang menunjukkan konflik batin dibawakan dengan menggunakan bantuan media lain seperti topeng, patung, maupun ditarikan lebih dari satu orang. Dengan begitu penonton dapat mengerti bahwa sang penari sedang mengalami pertentangan dalam batinnya karena terdapat media yang menyimbolkan keinginan maupun harapan yang tidak sejalan dengan kenyataan atau realita yang dialami oleh penari.

Karya ini menggunakan media seni video untuk memvisualisasikan konflik batin tersebut. Media seni video membuka kemungkinan untuk merekayasa visual tarian tersebut. Pada karya "Kinan" rekayasa dilakukan dengan memanipulasi bayangan sang penari sebagai visualisasi dari konflik batin. Judul "Kinan" diambil dari nama penari yang memerankan yaitu Kinanti Sekar Rahina. Koreografi dari tarian ini juga dibuat oleh Kinan sendiri sebagai bentuk dari konflik batin yang dialaminya. Sedangkan bayangan yang direkayasa dapat menjadi simbol yang mewakili keinginan atau harapan yang saling bertentangan dengan realita hidup penari sehingga dapat menggambarkan konflik yang terjadi dalam diri sang penari. Tujuan dari pembuatan karya seni video "Kinan" ini adalah mengeksplorasi bayangan sebagai bentuk konflik batin seorang penari sebagai gambaran pesan tentang eksistensi diri seorang penari serta memberikan kompleksitas lewat gestur tentang bagaimana mencintai budaya sendiri.

Di Indonesia, video seni berkembang dengan baik. Salah satu pelopornya adalah Krishna Murti. Seni video mempunyai akar sejarah yang berbeda dengan film seni, jika film seni berakar dari sinema, seni video berakar dari seni rupa ( Krishna Murti, 2009: 225). Krishna Murti mengatakan bahwa seni video muncul akibat imbas gerakan fluxus, yaitu gerakan pembaharuan yang menghilangkan batas antara seni pertunjukan seperti musik, tari dan teater, seni rupa dan seni film yang kemudian dihibridisasi menjadi bentuk baru. Melalui seni video seorang seniman dapat menampilkan sebuah karya yang lebih menarik karena menggunakan visual yang bergerak dan lebih atraktif. Seni video merupakan fusi antara seni visual, teknologi terkini dan citra bergerak yang ditransformasikan menjadi objek baru oleh seniman pembuatnya (Elwes, 2005: 11). Menurut Elwes (1991: 108), seni video 
atau video arts adalah sebuah praktek yang melibatkan ruang lain di luar dirinya secara menyeluruh seperti seni rupa instalasi dan performance art yang kemudian didistribusikan melalui galerigaleri.

Visualisasi yang terjadi dalam karya ini merupakan proses transformasi atau perubahan bentuk dari sebuah perasaan menjadi sebuah gambar. Perasaan yang dimaksud di sini adalah hasil dari konflik batin penari, di antaranya perasaan sedih, bimbang, takut, dan lain-lain. Perasaanperasaan tersebut diinterpretasikan ke dalam sebuah simbol yang berupa bayang penari. Menurut Darwanto, visualisasi merupakan suatu bentuk pengungkapan ide atau gagasan yang telah dituangkan dalam rangkaian kata-kata menjadi bentuk gambar, atau dengan kata lain mengubah bahan yang bersifat auditif menjadi bahan yang bersifat visual (1994:112). Perasaan penari diungkapkan ke dalam sebuah gagasan atau ide dalam bentuk kata-kata yang disusun menjadi puisi. Melalui puisi tersebut kemudian dibentuk menjadi sebuah gambar atau visual.

Menurut Robert A. Baron (2005:194), konflik adalah proses yang terjadi ketika individu atau kelompok mempersepsikan bahwa kepentingan orang lain tidak sejalan dengan kepentingan pribadi mereka. Elemen kunci dalam konflik meliputi, yaitu (1) kepentingan yang bertentangan di antara kedua belah pihak, (2) belief dari setiap pihak bahwa pihak lain akan atau telah mengambil langkah yang bertentangan dengan kepentingan mereka, (3) kesadaran akan adanya kepentingan yang bertentangan, dan (4) tindakan yang mengintervensi kepentingan pihak lain. Elemen-elemen tersebut yang membuat seseorang mengalami konflik dengan orang lain maupun diri sendiri. Munculnya konflik dipengaruhi dari faktor-faktor sosial seperti atribusi yang salah, komunikasi yang buruk, kecenderungan untuk mempersepsikan pandangan sendiri sebagai objektif, dan karakter pribadi. Bentuk konflik dapat dibagi menjadi dua, yaitu konflik interpersonal dengan sesama individu dan konflik intrapersonal yang hanya ada dalam diri individu yang bersangkutan. Konflik intrapersonal membuat seorang tokoh berada di antara kekuatan keinginan, tujuan, dan sistem nilai yang sama kuat tapi yang saling bertentangan. Konflik intrapersonal disebut juga dengan konflik batin.

\section{Pembahasan}

Karya seni video "Kinan"
menceritakan tentang seorang penari
bernama Kinanti Sekar Rahina yang
mengalami pertentangan batin dalam
menentukan eksistensi dirinya. Sebagai
seorang penari yang tumbuh besar dalam


lingkungan budaya Jawa namun memiliki ketertarikan pada budaya luar, yaitu tari balet. Ia mempunyai keinginan yang besar untuk menjadi seorang penari balet dan guru balet. Keinginannya untuk eksis menjadi seorang penari balet harus bertentangan dengan tuntutan melestarikan tarian Jawa. Tarian Jawa yang sudah dikenalnya sejak kecil dan saat sekarang ini sedikit demi sedikit telah tergerus oleh budaya luar. Banyak orang telah meninggalkan tarian Jawa dan lebih suka menarikan tarian-tarian modern yang lebih banyak terpengaruh oleh budaya luar. Hal ini membuatnya tergerak untuk dapat menjaga dan melestarikan budaya, khususnya tari Jawa. Pertentangan antara keinganan dengan realita yang sesungguhnya tersebut membuat konflik dalam diri Kinan.

Metode pembuatan karya seni video "Kinan" ini mengacu pada tahapan penciptaan dengan terminologi eksplorasi, eksperimen dan pembentukan atau perwujudan. Sedangkan proses produksi seni video tersebut mengacu pada proses produksi film atau televisi, yaitu development, pre-production, production dan post-production (Cleve, 2006:9). Development merupakan proses tahapan mencari dan mengembangkan ide, preproduction adalah tahapan persiapan segala kebutuhan produksi, production adalah proses pengumpulan materi, syuting dan lainnya, sedangkan postproduction adalah proses menyatukan semua materi menjadi karya seni video.

\section{Eksplorasi}

Ide dari karya ini berasal dari sebuah puisi yang di tulis oleh Kinanti Sekar Rahina. Puisi tersebut menceritakan tentang pergulatan batinnya dalam menemukan jati dirinya sebagai seorang penari. Di bawah ini adalah puisi yang ditulis oleh Kinan:

Aku seorang penari...

Tubuh adalah media yang slalu aku gunakan untuk mengungkapan moment dalam kehidupanku.

Dari kehidupan yang kujalani.. $k u$ temukan banyak hal, dari mulai perjalanan kehidupan dan kesenian entah itu baik atau buruk.

aku seorang penari mempunyai keinginan dan cita-cita yang berbeda, aku bercita-cita ingin menjadi guru ballet dan koreografer jogja.

Tapi, aku punya tradisi warisan kebudayaan yang harus selalu aku kenalkan kepada seluruh dunia lewat tubuhku.

Pergulatan batin untuk menemukan jati diri dan ciri khas tubuhku adalah "mampu mengasihi dan memahami diri sendiri"

aku harus belajar mengendalikan seluruh tubuhku.. tidak hanya itu, jiwa, raga dan batinku harus menjadi satu untuk bisa menciptakan sebuah tarian jiwa yang terisi bukan hanya gerakan semata yang nantinya hadir di setiap gerakan, seluruh raga akan mengikuti jiwa yang akan menuntun tarian ku dengan ihklas. 


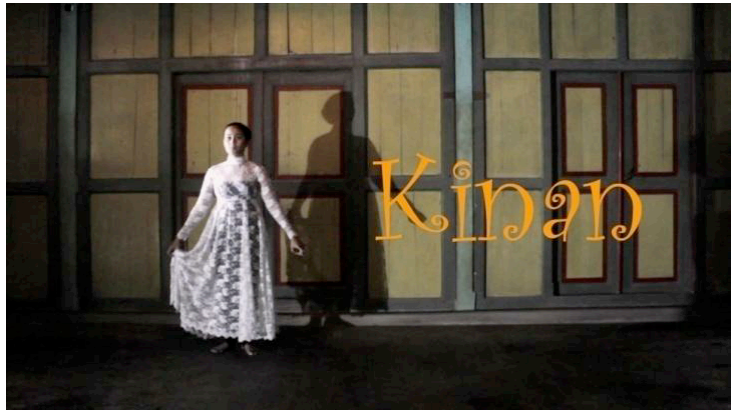

Capture.1.1. Karya seni video "Kinan".

Dalam tahap eksplorasi ini dilakukan proses interpretasi naskah puisi ke dalam bentuk visual. Ide yang didapatkan dalam proses eksplorasi ini adalah menggunakan bayang sebagai simbol dari pergulatan batin. Ruang yang tidak terkena sinar karena terlindung suatu benda dalam kamus besar Bahasa Indonesia disebut dengan bayang. Sehingga bayang adalah sebuah area gelap yang terbentuk dari cahaya yang tertutup atau terhalang sebuah objek dan berbentuk sesuai dengan bentuk objek yang menghalanginya.

Bayang dari sang penari akan dibuat seolah-olah hidup dan ikut menarikan tarian tersebut. Bayang menjadi simbol dari keinginannya menjadi seorang penari balet dan dirinya menjadi simbol realita untuk tetap melestarikan tarian Jawa. Sehingga seolah-olah terjadi adu tarian antara sang penari dengan bayangnya yang pada akhirnya membentuk sebuah tari kreasi yang memadukan antara tari tradisional dengan modern. Bayang yang pada awal melakukan gerakan yang berbeda, kemudian pada pada akhirnya melakukan gerakan yang selaras dengan tubuh sang penari.

\section{Eksperimen}

Pada tahapan ini dilakukan proses integrasi ide-ide dengan faktor-faktor eksternal. Salah satunya melakukan observasi dengan melihat karya-karya seni lain yang menggunakan objek bayang maupun tarian-tarian yang sudah ada. Salah satu karya seni yang menggunakan bayang sebagai media cerita adalah wayang kulit. Pada proses pengamatan pada karya seni wayang ditemukan kesulitan dalam menentukan jatuhnya bayang pada latar agar bayang tidak bersentuhan dengan penari. Selain itu jarak antara objek dengan sumber cahaya juga mempengaruhi besar atau kecil dari bayang. Penyesuaian jarak dan sumber cahaya diperlukan untuk mendapatkan mendapat bayang yang diinginkan.

Observasi juga dilakukan pada tari balet dan tari tradisional Jawa yang akan dipadukan menjadi satu. Kesulitan pada saat eksperimen adalah menggabungkan kedua tarian tersebut dengan iringan yang bergantian agar perpindahannya tidak terkesan mendadak. Iringan tari balet dengan iringan tarian Jawa memiliki tempo yang berbeda. Iringan tari yang digunakan dalam karya ini adalah iringan tari bedaya yang temponya lebih lambat 
dibandingkan dengan tempo iringan tari balet.

\section{Perwujudan}

\section{a) Pra Produksi}

1) Riset, Pengembangan Ide, dan Penulisan Treatment

Riset visual dilakukan dengan mencoba menyinari sebuah objek dengan cahaya lampu yang diletakkan pada beberapa sudut tertentu sampai diperoleh titik yang pas untuk menghasilkan bayang yang diinginkan. Hal tersebut dilakukan untuk mempermudah proses editing dan spesial efek penggabungan penari dengan bayangnya. Karena menggunakan teknik cropping maka bayang penari tidak boleh tertutup oleh tubuh penari. Ide dasar dari karya ini adalah memvisualisasikan puisi yang ditulis oleh Kinan. Riset gerakan sebagai dasar koreografi dilakukan untuk dapat menginterpretasikan pesan dari puisi tersebut.

Setelah pengembangan ide, dilakukan pembuatan treatment dari naskah puisi tersebut. Treatment adalah pengembangan jalan cerita dari sebuah sinopsis, yang di dalamnya berisi plot secara detail, namun cukup padat (Elizabeth, 2004:86). Secara garis besar, treatment dapat diartikan sebagai kerangka dari cerita keseluruhan. Pembuatan treatment tersebut juga dapat dilakukan dalam pembuatan sebuah seni video karena proses produksi yang digunakan sama. Hal ini dapat mempermudah proses pengambilan gambar sekaligus dapat menjadi tolakan proses editing gambar. Dalam karya, karya seni video "Kinan" akan dibagai dalam tiga sequence, yaitu:

\begin{tabular}{|c|c|}
\hline $\mathrm{Sq}$ & Deskripsi \\
\hline 1 & $\begin{array}{l}\text { Memperlihatkan Kinan sebagai } \\
\text { seorang penari Jawa namun } \\
\text { memiliki keinginan untuk } \\
\text { menjadi penari balet. Tubuh } \\
\text { Kinan menarikan tari bedaya, } \\
\text { sementara bayangnya menarikan } \\
\text { tari balet. Kinan menari dengan } \\
\text { bayangnya, mencoba mencari } \\
\text { perpaduan gerakan yang selaras. } \\
\text { Kinan mencoba mengikuti } \\
\text { gerakan bayang dan sebaliknya } \\
\text { bayang juga mencoba mengikuti } \\
\text { gerakan Kinan. }\end{array}$ \\
\hline 2 & $\begin{array}{l}\text { Tercipta sebuah perpaduan } \\
\text { gerakan yang saling mengisi } \\
\text { antara Kinan dengan bayangnya. } \\
\text { Walaupun tidak sama } \\
\text { gerakannya namun dapat tercipta } \\
\text { sebuah gerakan yang harmonis. } \\
\text { Kinan dan bayang menari } \\
\text { dengan gerakan perpaduan dari } \\
\text { tari Jawa dengan balet. }\end{array}$ \\
\hline
\end{tabular}




\begin{tabular}{|l|lr|}
\hline 3 & Pada akhirnya gerakan Kinan \\
dengan bayangnya menjadi \\
selaras kembali. Kinan mampu \\
menemukan eksistensi dirinya \\
sebagai seorang penari dengan \\
menarikan tari kreasi yang \\
memadukan antara tarian Jawa \\
dengan balet.
\end{tabular}

Dengan membagi cerita dalam tiga bagian, tangga dramatik dari seni video dapat ditentukan. Pada sequence yang pertama diperlihatkan permasalahan yang sedang dihadapi oleh Kinan, yaitu pergulatan batinnya tentang eksistensi dirinya sebagai seorang penari. Permasalahan tersebut digambarkan dengan perbedaan tari dari Kinan dengan bayangnya. Kemudian sequence dua menunjukkan kenaikan grafik pada unsur dramatik dengan adegan Kinan dan bayangnya melakukan gerakan tari yang saling mengisi. Keduanya menarikan tari kreasi perpaduan antara tari balet dengan tari Jawa. Pada scquence terakhir, Kinan dan bayang melakukan gerakan yang sama atau selaras. Hal tersebut merupakan anti klimaks dari permasalahan yang dihadapi oleh Kinan dalam mencari eksistensi dirinya sebagai seorang penari.
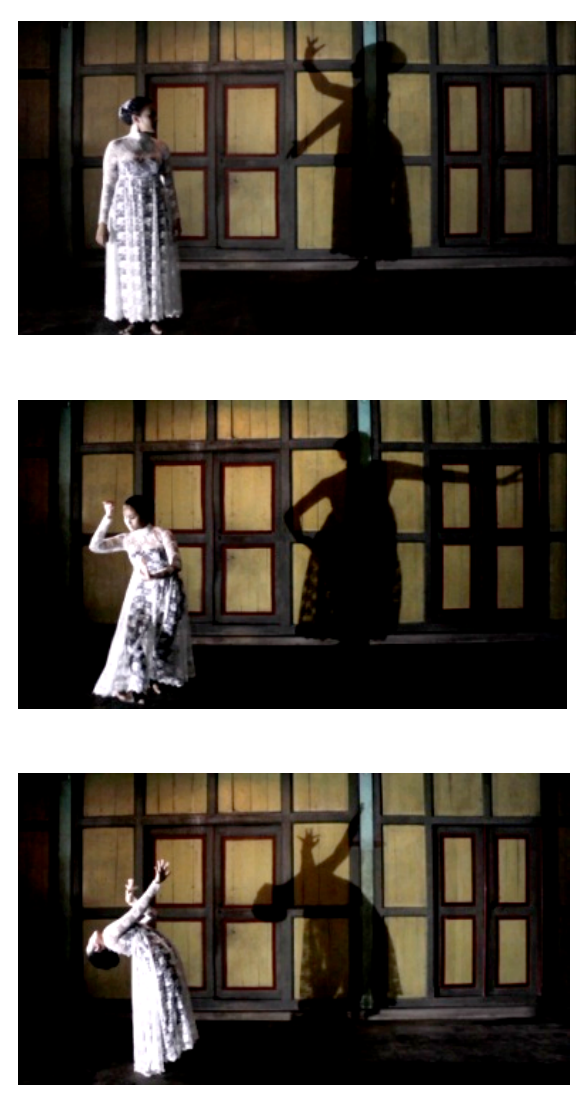

Capture.1.2. Pembagian treatment menjadi 3 sequence.

\section{2) Desain Program}

Desain program merupakan perencanaan dari sebuah karya seni video yang di antaranya meliputi:

\section{a. Judul}

Seperti yang sudah dijelaskan di atas bahwa judul karya ini diambil dari nama penarinya yaitu Kinanti Sekar Rahina. Alasan lain, judul "Kinan" sebagai representasi pesan dalam karya seni video ini yaitu menunjukkan konflik batin yang dialami oleh penarinya. Selain itu, cerita yang diambil merupakan kisah nyata yang dialami oleh Kinan. 


\section{b. Durasi}

Durasi dari karya ini 6 menit

31 detik.

\section{c. Teknik}

Teknik produksi yang dilakukan menggunakan live shooting menggunakan 2 buah kamera. Pada master shot dilakukan pengambilan gambar sebanyak dua kali dalam posisi kamera yang tidak berubah (steady). Proses itu dilakukan untuk mempermudah konsep cropping pada saat editing dan spesial efek. Pencahayaan menggunakan dua buah lampu sebagai sumber cahaya, satu sebagai lampu utama untuk membentuk bayang dan yang lain untuk menerangi objek

\section{d. Visual}

Menunjukkan bayang dari seorang penari yang seolah-olah hidup dan menari bersama penarinya. Bayang sebagai simbol konflik batin yang dialami oleh penari ditampilkan dengan gaya surealis.

\section{e. Suara}

Unsur-unsur suara yang digunakan dalam karya ini adalah musik dan efek suara, tanpa dialog. Musik dibagi dalam tiga bagian, yaitu: pengiring tari bedaya, pengiring tari balet, dan pengiring tari kreasi. Iringan tari kreasi menggunakan instrumeninstrumen tradisional untuk menonjolkan konten budaya Jawa. Hal ini menggambarkan bahwa sang penari memiliki keinginan yang kuat untuk melestarikan budayanya di tengah arus masuknya budaya luar.

\section{f. Format}

Format produksi atau format video pada saat pengambilan gambar menggunakan Full HD PAL karena untuk kebutuhan proses editing, agar pada saat cropping kualitas gambar tetap bisa maksimal. Pada saat proses cropping gambar biasanya akan dilakukan perubahan ukuran untuk memadukan gambar satu dengan yang lainnya. Adanya perubahan ukuran gambar pada saat proses editing akan mempengaruhi kualitas dari gambar. Sedangkan untuk format presentasi menggunakan DVD PAL dan MP4 agar karya dapat didistribusikan melalui keping DVD maupun diunggah ke berbagai kanal video yang terakses internet.

\section{3) Kru Produksi}

Dalam proses produksi seni video diperlukan banyak sumber daya 
manusia, namun tidak sebanyak kru dalam pembuatan sebuah film yang prosesnya lebih kompleks. Kru yang kompeten dalam bidangnya dan bisa bekerja secara kolektif dalam sebuah tim sangat penting. Kru produksi seni video "Kinan" antara lain, penata kamera, penata lampu, penata suara, dan artistik.

\section{4) Hunting Lokasi}

Lokasi yang digunakan dalam karya video ini, ingin menonjolkan unsur Jawa sebagai latarnya. Hal ini sesuai dengan latar belakang dari penari yang merupakan orang Jawa.

Sehingga latar dari karya ini menggunakan gebyok, yaitu sebuah dinding yang terbuat dari kayu yang biasa terdapat pada rumah-rumah tradisional Jawa.

\section{5) Storyboard}

Setelah semua proses pra produksi dilakukan, hal terakhir yang dilakukan adalah membuat storyboard. Storyboard adalah sebuah konsep matang yang dituangkan dalam bentuk visual sederhana yang disertai penjelasan detail tentang gambaran visual, efek visual, audio, dan efek audio (Bonafix, 2005:33). Storyboard memungkinkan seluruh pihak yang terlibat bisa melihat garis besar dari karya seni video tersebut. Fungsi dari storyboard adalah untuk mempermudah proses pengambilan gambar di lokasi.

\section{b) Produksi}

Proses pengambilan gambar seni video "Kinan" menggunakan multi kamera sehingga prosesnya memakan waktu sekitar satu hari. Penggunaan multi kamera selain untuk mengefisiensikan waktu juga agar mempermudah proses editing. Kamera utama berfungsi sebagai master shot atau gambar utama dengan ukuran gambar full shot, sehingga penari terlihat dari kaki sampai kepala dengan latar terlihat keseluruhannya. Kamera kedua mengambil gambar dengan ukuran medium shot yang nantinya berfungsi sebagai gambar insert atau sisipan dari gambar utama.
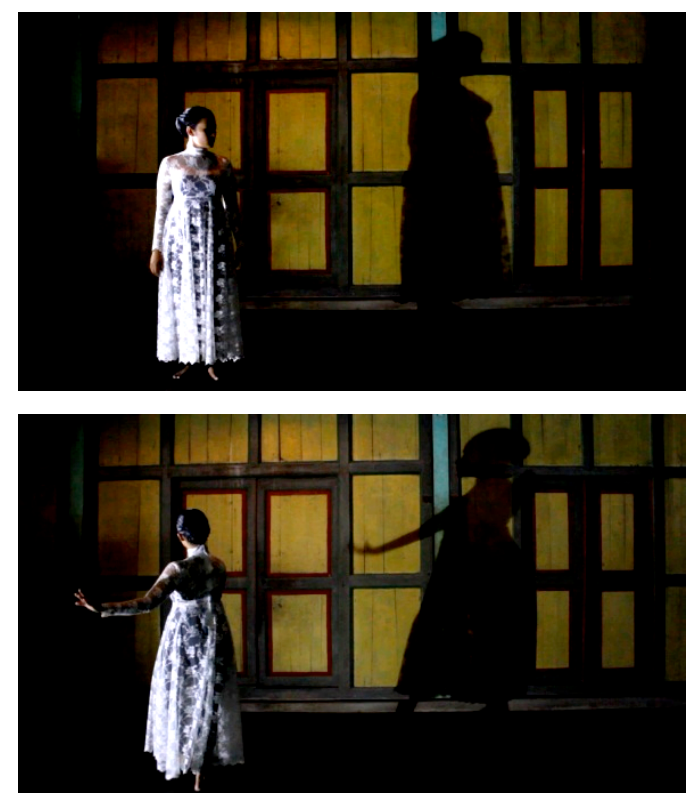

Capture.1.3. master shot 1 dan master shot 2

Pengambilan gambar dilakukan dua kali untuk membuat visual efek bayang 
yang seolah-olah hidup. Hal ini merupakan salah satu cara yang lebih sederhana dibanding menggunakan blue screen yang membutuhkan biaya yang lebih besar dalam proses visual efek. Selain itu teknik blue screen membutuhkan peralatan dan proses yang lebih, seperti: jumlah lampu yang lebih banyak untuk menghasilkan pencahayaan merata, kain berwarna biru, dan proses editing yang lebih rumit. Sedangkan teknik cropping hanya memerlukan dua buah gambar yang ukuran dan latarnya sama. Caranya adalah dengan melakukan dua kali pengambilan gambar tanpa memindah atau menggeser tripod kamera. Gambar pertama fokus pada penari dan gambar kedua pada bayang penari. Hal yang harus diperhatikan adalah pada saat proses pengambilan gambar bayang tidak boleh tertutup oleh tubuh penari karena akan sulit untuk melakukan cropping karena gambar yang bertumpuk. Trik yang digunakan untuk mengatasi masalah tersebut adalah pengubahan sudut sumber cahaya pada saat pengambilan bayang. Pengubahan sudut sumber cahaya menghasilkan jatuhnya bayang akan lebih jauh. Koreografi dari dua jenis tarian (bedaya dan balet) dikonsep agar ketika dibawakan tidak ada gerakan yang menyilang, sehingga tubuh dan bayang tidak akan menumpuk.

\section{c) Paska Produksi}

Pada proses ini gambar yang sudah diambil kemudian disusun satu persatu kemudian dilakukan proses cropping. Teknik cropping adalah teknik memotong atau menghilangkan bagian atau area tertentu pada sebuah gambar. Hal ini juga sering dilakukan pada proses editing foto. Pada karya ini, bagian yang digunakan adalah tubuh penari pada video pertama dan bagian bayang pada video kedua. Pemotongan pada karya video ini dilakukan secara selection, yaitu mengikuti atau menyesuaikan dengan tubuh penari maupun bayangnya. Kemudian untuk penyempurnaan visualisasi dramatisnya dilakukan coloring dan penambahan ilustrasi musik.

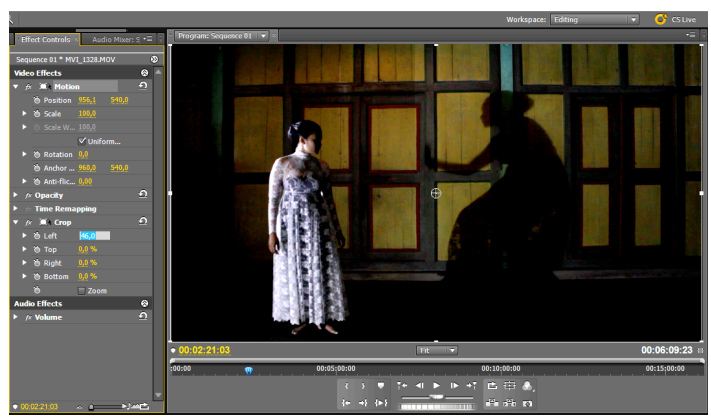

Capture.1.4. Teknik editing cropping.

\section{Kesimpulan}

Media seni video dipilih karena memiliki karakteristik yang kuat dalam menyampaikan pesan kepada penonton. Media seni video yang bersifat audio visual memudahkan penonton menangkap pesan karena mampu memvisualisasi konsep atau gagasan 
dalam bahasa gambar dan suara.

Visualisasi konflik batin digambarkan melalui bayang sebagai simbol pergulatan batin sang penari. Konflik batin yang dirasakan sendiri oleh penari sebagai sesuatu yang tak nampak menjadi terlihat sehingga penonton dapat mengetahui konflik apa yang sedang dialami. Dengan unsur sinematik ini, sebuah konflik batin dapat divisualisasikan. Penonton dapat ikut merasakan konflik batin yang dialami oleh penari pada saat menonton video ini.

Karya seni video "Kinan"
menekankan pada visualisasi konflik
batin menggunakan bayang yang seolah-
olah hidup, sehingga memberikan
gambaran tentang harapan yang tidak
sesuai dengan realita yang harus
dihadapi. Harapan untuk menjadi seorang
penari balet harus bertentangan dengan
kesadaran untuk mencintai dan
melestarikan budaya sendiri. Karya seni
video ini diharapkan mampu memberikan
gambaran tentang bagaimana menghargai
budaya sendiri, sehingga dapat
menumbuhkan rasa cinta dan bangga
terhadap budayanya.

\section{Daftar Rujukan}

\section{Daftar Sumber Buku}

Baron, Robert A. 2005. Psikologi Sosial Jilid 2. Jakarta: Erlangga

Bonafix, Dominicus N. 2005. Animasi $3 D$ Profesional dengan Maya. Jakarta: PT Elex Media Komputindo.

Cleve, Bastian. 2006, Film Production Management, Third Edition, Focal Press, Burlington, MA.

Elwes, Catherine. 2005, Video Art : A Guided Tour, I.B. Tauris \& Co Ltd, London.

Lutters, Elizabeth. 2004. Kunci Sukses Menulis Skenario. Jakarta: Grasindo.

Murti, Khrisna. 2009, Titik Temu Seni Video dan Seni Film : Esai Tentang Seni Video dan Media Baru, Indonesian Visual Art Archive (IVAA), Yogyakarta.

Sastro, Darwanto S. 1994. Produksi Acara Televisi. Yogyakarta: Duta Wacana University Press.

Soedarsono, R.M. 1992. Pengantar Apresiasi Seni. Jakarta: Balai Pustaka 
Sense Vol 4 | No 2 | Mei 2021 
Antonius Janu Haryono, Sazkia Noor Anggraini

Bayang sebagai Eksplorasi Konflik Batin dalam Visualisasi Puisi pada Karya Seni Video "Kinan" 